\title{
LINGUA
}

Jurnal Bahasa, Sastra, dan Pengajarannya

Fakultas Bahasa dan Seni, Universitas Negeri Semarang

Kampus Sekaran, Gunungpati, Semarang, Indonesia 50229 Telp. (024) 8508010

surel: jurnal.lingua@mail.unnes.ac.id \& lingua.fbs@mail unnes.ac.id http://journal.unnes.ac.id/nju/index.php/lingua

\section{KONTRIBUSI MOTIVASI BELAJAR DAN PENGUASAAN KOSAKATA TERHADAP KETERAMPILAN MENULIS TEKS EKSPOSISI SISWA SMA}

\author{
Rita Rozana ${ }^{1}$, Syahrul R. ${ }^{2}$, Irfani Basri ${ }^{3}$ \\ Program Studi Pendidikan Bahasa dan Sastra Indonesia \\ Program Magister Fakultas Bahasa dan Seni Universitas Negeri Padang
}

\section{Info Artikel}

Sejarah artikel:

Diterima

November 2017

Disetujui

Desember 2017

Dipublikasikan

Januari 2018

\section{Kata kunci:}

belajar, kontribusi,

kosakata, motivasi,

teks eksposisi.

\section{Keywords:}

contribution, motivation,

learning,

vocabulary,

exposition texts.

\begin{abstract}
ABSTRAK
Penelitian ini bertujuan untuk: (1) menjelaskan kontribusi motivasi belajar terhadap keterampilan menulis teks eksposisi siswa kelas X MAN 1 Bukittinggi; (2) menjelaskan kontribusi penguasaan kosakata terhadap keterampilan menulis teks eksposisi siswa kelas X MAN 1 Bukittinggi; (3) menjelaskan kontribusi motivasi belajar dan penguasaan kosakata secara bersama-sama terhadap keterampilan menulis teks eksposisi siswa kelas X MAN 1 Bukittinggi. Sampel penelitian dari jumlah populasi setiap kelas, yaitu 43 siswa. Data penelitian ini berupa skor hasil pengisian angket motivasi belajar, skor hasil tes penguasaan kosakata, dan skor hasil tes keterampilan menulis teks eksposisi. Berdasarkan hasil penelitian dapat disimpulkan bahwa motivasi belajar dan penguasaan kosakata dapat dijadikan prediktor untuk meningkatkan hasil belajar keterampilan menulis teks eksposisi. Oleh sebab itu, untuk meningkatkan hasil belajar keterampilan menulis, maka siswa diberikan motivasi belajar menulis dan penguasaan kosakata.
\end{abstract}

\begin{abstract}
This study aims to: (1) explain the contribution of learning motivation to the writing skills of exposition text of class X MAN 1 Bukittinggi students; (2) explain the contribution of vocabulary mastery to the writing skills of exposition text of class X MAN 1 Bukittinggi students; (3) explain the contribution of learning motivation and vocabulary mastery to the writing skills of exposition text of class X MAN 1 Bukittinggi students. The sample of the study of the total population in each class is 43 students. The data of this research are the score taken from the result of learning motivation questionnaire, the score of vocabulary test, and the score of test of exposition text writing skill. Based on the results of the research, it can be concluded that the motivation of learning and mastery of vocabulary can be used as a predictor to improve the results of learning skills of writing exposition text. Therefore, to improve learning outcomes in writing skills, the students are given the motivation to learn writing and mastering vocabulary.
\end{abstract}




\section{PENDAHULUAN}

Pendidikan merupakan upaya transmisi pengetahuan kepada peserta didik yang memiliki tujuan tertentu. Sesuai dengan Undang-undang Nomor 20 Tahun 2003 Pasal 3 yaitu "Pendidikan nasional berfungsi mengembangkan kemampuan dan membentuk watak serta peradaban bangsa yang bermartabat dalam rangka mencerdaskan kehidupan bangsa, bertujuan untuk berkembangnya potensi peserta didik agar menjadi manusia yang beriman dan bertakwa kepada Tuhan Yang Maha Esa, berakhlak mulia, sehat, berilmu, cakap, kreatif, mandiri, dan menjadi warga negara yang demokratis serta bertanggung jawab." Oleh karena itu, pendidikan akan mengubah pribadi peserta didik menjadi lebih baik.

Tujuan pendidikan yang tertera dalam undang-undang sejalan dengan tujuan pembelajaran, khususnya pembelajaran bahasa Indonesia Kurikulum 2013. Adapun tujuan pembelajaran bahasa Indonesia dalam Kurikulum 2013 SMA/MA sederajat bertujuan untuk menciptakan pembelajaran yang aktif, kreatif, komunikatif, interaktif, dan menyenangkan (Kemendikbud Nomor 69 Tahun 2013). Untuk mencapai tujuan tersebut, diperlukan komunikasi dua arah antara guru dan siswa selama proses pembelajaran. Hal ini bertujuan agar siswa termotivasi untuk lebih aktif dalam mengemukakan pendapat, bertanya, dan kreatif selama proses pembelajaran. Kondisi belajar tersebut secara tidak langsung dapat membantu siswa dalam mengembangkan keterampilan berbahasa mereka, khususnya dalam keterampilan menulis.

Menurut Mahsun (2014:94), bahasa Indonesia di samping memberi penegasan akan pentingnya kedudukan bahasa Indonesia sebagai bahasa nasional yang mempersatukan berbagai etnis yang berbeda latar belakang bahasa lokal dan kedudukannya sebagai bahasa resmi negara, bahasa Indonesia juga sebagai penghela ilmu pengetahuan. Bahasa Indonesia sebagai penghela ilmu pengetahuan, tidak hanya sebagai sarana untuk mengomunikasikan ilmu pengetahuan tetapi juga sebagai sarana untuk mengembangkan dan mentransmisi ilmu pengetahuan itu sendiri dari generasi ke generasi.

Salah satu jenis tulisan yang harus dikuasai siswa MA sesuai dengan Kurikulum 2013 adalah pada KI (Kompetensi Inti) ke-4 dan KD (Kompetensi Dasar) 4.2 yaitu memproduksi teks anekdot, eksposisi, laporan hasil observasi, prosedur komplek, dan negosiasi yang koheren sesuai dengan karakteristik teks yang akan dibuat baik secara lisan maupun tulisan. Keterampilan menulis teks eksposisi siswa dianggap sebagai salah satu keterampilan menulis yang sulit oleh siswa. Hal tersebut disebabkan oleh dalam tulisan eksposisi dituntut untuk memberikan paparan yang jelas tentang hal yang dikembangkan dalam tulisan. Hal tersebut membutuhkan tingkat ketelitian dan pemahaman yang tinggi dalam mengembangkan tulisan. Tujuan KD ini ialah agar siswa mampu menulis teks eksposisi yang koheren sesuai dengan karakteristik teks.

\section{METODE PENELITIAN}

Penelitian yang dilakukan adalah penelitian yang bersifat kuantitatif dengan menggunakan metode deskriptif. Desain penelitian ini adalah korelasional (corelation research). Penelitian korelasi dilakukan untuk mengetahui kekuatan hubungan antara variabel bebas $\left(\mathrm{X}_{1}\right.$ dan $\left.\mathrm{X}_{2}\right)$ terhadap variabel terikat (Y).

Populasi penelitian adalah seluruh siswa kelas X MAN 1 Bukittinggi tahun ajaran 2015/2016 berjumlah282 siswa. Penarikan 
sampel menggunakan teknik proportional random sampling. Sampel penelitian diambil $15 \%$ dari jumlah populasi siswa setiap kelas, yaitu 43 siswa.

Penelitian ini terdiri atas tiga variabel, yaitu dua variabel bebas (independent) dan satu variabel terikat (dependent). Variabel bebas adalah motivasi belajar $\left(\mathrm{X}_{1}\right)$ dan penguasaan kosakata $\left(\mathrm{X}_{2}\right)$, sedangkan variabel terikat adalah keterampilan menulis teks eksposisi (Y). Data penelitian ini sebagai berikut. Data untuk variabel motivasi belajar $\left(\mathrm{X}_{1}\right)$ adalah skor hasil pengisian angket motivasi belajar. Variabel penguasaan kosakata $\left(\mathrm{X}_{2}\right)$ adalah skor hasil tes penguasaan kosakata. Selanjutnya, data variabel keterampilan menulis teks eksposisi (Y) adalah skor hasil tes keterampilan menulis teks eksposisi. Kemudian data diubah ke dalam bentuk nilai.

Instrumen penelitian terdiri atas tiga, yaitu angket, tes objektif, dan tes unjuk kerja. Angket digunakan untuk mengetahui motivasi belajar siswa, tes objektif digunakan untuk mengetahui penguasaan kosakata, dan tes unjuk kerja digunakan untuk mengetahui hasil keterampilan menulis teks eksposisi. Adapun langkah-langkah dalam mengembangkan instrumen penelitian adalah sebagai berikut.

a. Mengkaji teori-teori yang berkaitan dengan ketiga variabel penelitian.

b. Menentukan indikator berdasarkan kerangka teori yang digunakan.

c. Menetapkan kisi-kisi ketiga variabel penelitian.

d. Menyusun butir-butir pernyataan angket motivasi belajar dan tes penguasaan kosakata serta membuat rubrik penilaian keterampilan menulis.

e. Melakukan validasi instrumen penelitian kepada validator.

f. Melakukan uji coba instrumen untuk mengetahui validitas dan reliabilitas serta daya pembeda dan tingkat kesukaran soal.

Penguasaan kosakata untuk uji coba terdiri atas 40 butir soal. Setelah dilakukan uji validitas dengan menggunakan rumus Biserial, diperoleh 32 butir soal yang dinyatakan valid dan reliabel. Jadi, 32 butir soal dapat digunakan sebagai instrumen penelitian.

Berdasarkan penghitungan taraf kesukaran pada setiap butir soal menunjukkan bahwa dari 40 soal tes penguasaan kosakata diperoleh 2 soal tergolong sukar, 28 soal tergolong sedang, dan 10 soal tergolong mudah. Selanjutnya, penghitungan daya pembeda soal menunjukkan bahwa dari 40 butir soal tes penguasaan kosakata, diperoleh 4 soal memiliki daya pembeda pada kualifikasi baik sekali, 28 soal memiliki daya pembeda pada kualifikasi baik, 7 soal memiliki daya pembeda pada kualifikasi cukup, dan 1 soal memiliki daya pembeda pada kualifikasi jelek.

Langkah-langkah pengumpulan data adalah sebagai berikut. Pertama, angket diberikan kepada siswa. Kedua, siswa mengisi setiap pernyataan dalam lembaran angket dengan membubuhkan tanda centang. Ketiga, siswa diberikan tes objektif untuk mengukur penguasaan kosakata. Keempat, siswa mengisi lembar jawaban dengan membubuhkan tanda silang (X) pada pilihan jawaban yang dianggap paling benar. Kelima, siswa diberikan tes unjuk kerja untuk mengukur keterampilan menulis teks ekposisi. Keenam, siswa mengerjakan tes unjuk kerja menulis. Ketujuh, semua lembar jawaban yang telah terkumpul diperiksa sesuai dengan aspek dan kriteria yang telah ditetapkan.

Selanjutnya, dilakukan pengujian persyaratan analisis, yaitu (1) uji normalitas dengan menggunakan rumus Lilliefors, (2) uji homogenitas dengan menggunakan uji $\mathrm{F}$, dan (3) uji linieritas. Kemudian dilanjutkan dengan pengujian hipotesis. Langkah-langkah dalam 
pengujian hipotesis adalah sebagai berikut.

a. Hipotesis pertama dan kedua diuji dengan cara mengkorelasikan antara variabel bebas motivasi belajar $\left(\mathrm{X}_{1}\right)$ dan penguasaan kosakata $\left(\mathrm{X}_{2}\right)$ dengan variabel terikat keterampilan menulis teks eksposisi. Rumus yang digunakan adalah rumus uji korelasi Pearson Product Moment (PPM).

b. Hipotesis ketiga diuji dengan cara mengkorelasikan variabel motivasi belajar $\left(\mathrm{X}_{1}\right)$ dan penguasaan kosakata $\left(\mathrm{X}_{2}\right)$ secara bersama-sama dengan variabel keterampilan menulis teks eksposisi. Rumus yang digunakan adalah rumus uji korelasi ganda.

\section{HASIL DAN PEMBAHASAN}

\section{Kontribusi Motivasi Belajar terhadap Keterampilan Menulis Teks Eksposisi}

Angket motivasi belajar terdiri atas 40 butir pernyataan dengan rentangan skor 1-5. Skor maksimal yang diperoleh siswa adalah 190 dan skor minimal 129. Berdasarkan hasil analisis data diperoleh nilai tertinggi 95 , nilai terendah 64,50 , nilai rata-rata sebesar 79,98 dan standar deviasi sebesar 7,15. Berikut ini gambaran mengenai hasil motivasi belajar dibuat dalam bentuk diagram batang.

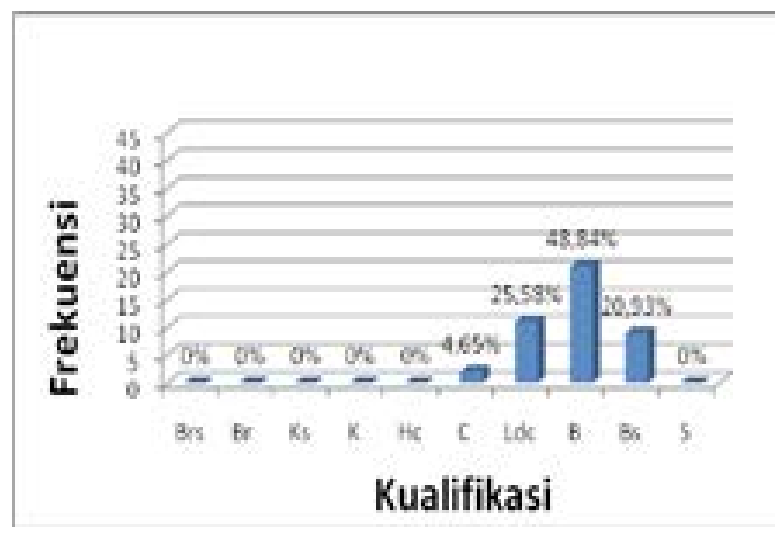

Gambar 1. Diagram Batang Motivasi Belajar
Diagram batang di atas dapat disimpulkan bahwa motivasi belajar siswa kelas X MAN1 Bukittinggi dikelompokkan menjadi 4 kategori sebagai berikut. Pertama, yang berada pada tingkat penguasaan (86-95\%) kualifikasi baik sekali berjumlah 9 orang (20,93\%). Kedua, yang berada pada tingkat penguasaan (76-85\%) kualifikasi baik berjumlah 21 orang (48,84\%). Ketiga yang berada pada tingkat penguasaan (66-75\%) kualifikasi lebih dari cukup berjumlah 11 orang $(25,58 \%)$. Keempat, yang berada pada tingkat penguasaan (36$45 \%)$ kualifikasi kurang berjumlah 2 orang (4,65\%).

Berdasarkan hasil penelitian, diketahui bahwa motivasi belajar memberikan kontribusi yang signifikan terhadap keterampilan menulis teks eksposisi, yaitu sebesar 22,2\% karena $t_{\text {hitung }}>t_{\text {tabel }}$ atau 3,418>2,629 dan memiliki persamaan regresi sederhana $\hat{Y}=33,87+0,35 X_{1}$. Hal ini menunjukkan bahwa keterampilan menulis teks eksposisi dipengaruhi oleh motivasi belajar menulis.

Temuan penelitian ini sejalan dengan pendapat Sardiman (2009:75), dalam kegiatan belajar, motivasi dapat dikatakan sebagai keseluruhan daya penggerak di dalam diri siswa yang menimbulkan kegiatan belajar, yang menjamin kelangsungan dari kegiatan belajar dan kegiatan belajar dan yang memberikan arah pada kegiatan belajar. Selanjutnya, Hamalik (2009:27) mengatakan bahwa motivasi dapat memberikan semangat kepada siswa dalam kegiatan belajarnya dan memberikan petunjuk atau perbuatan yang dilakukan. Hasil belajar bukan suatu penguasaan hasil latihan melainkan perubahan kelakuan. Semakin tinggi motivasi siswa dalam belajar maka mereka akan bersungguh dalam memahami materi pelajaran. Hal tersebut akan terlihat dari sikap dan tingkah laku siswa dalam belajar. 
Berdasarkan uraian di atas, dapat disimpulkan bahwa diperlukan motivasi belajar untuk mencapai tujuan pembelajaran, termasuk dalam pembelajaran menulis teks eksposisi. Keterampilan menulis setiap siswa akan berbeda, sesuai dengan tingginya motivasi yang ada pada masing-masing siswa. Siswa yang memiliki motivasi belajar yang tinggi terhadap pembelajaran menulis teks eksposisi akan memperoleh hasil yang lebih baik dibandingkan dengan siswa yang memiliki motivasi rendah.

\section{Kontribusi Penguasaan Kosakataterhadap Keterampilan Menulis Teks Eksposisi}

Tes penguasaan kosakata terdiri atas 32 butir soal yang berbentuk tes objektif. Skor maksimal yang diperoleh siswa adalah 31 dan skor minimal adalah 19. Berdasarkan hasil analisis data diperoleh nilai tertinggi sebesar 96,88 dan nilai terendah 59,38, nilai rata-rata sebesar 77,40 dan standar deviasi sebesar 9,75. Berikut ini gambaran penguasaan kosakata dibuat dalam bentuk diagram batang.

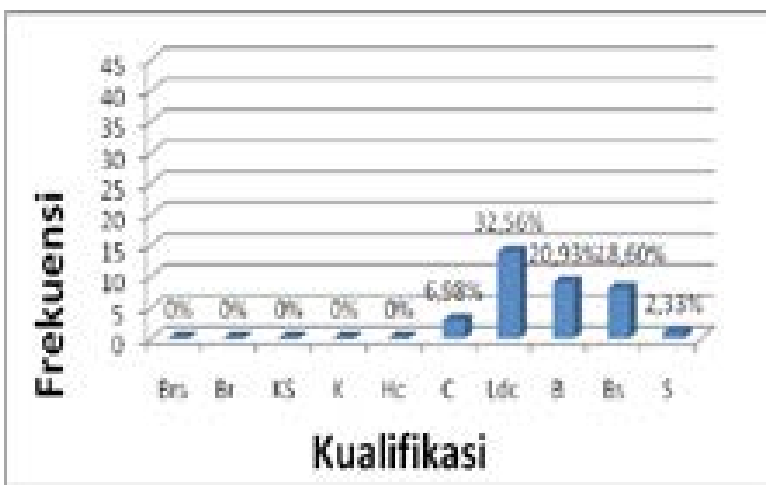

Gambar 2. Diagram Batang Penguasaan Kosakata

Diagram batang di atas, dapat disimpulkan bahwa penguasaan kosakata siswa kelas X MAN 1 Bukittinggi secara keseluruhan dikelompokkan menjadi 5 kategori sebagai berikut. Pertama, siswa yang mendapat nilai tertinggi terdiri atas 1 orang (96-100\%) dengan kualifikasi sempurna (2,33\%). Kedua yang berada pada tingkat penguasaan (8695\%) kualifikasi baik sekali berjumlah 8 orang $(18,60 \%)$. Ketiga, yang berada pada tingkat penguasaan (76-85\%) kualifikasi baik berjumlah 9 orang (20,93\%). Keempat, yang berada pada tingkat penguasaan (66-75\%) kualifikasi lebih dari cukup berjumlah 14 orang $(32,56 \%)$. Kelima, yang berada pada tingkat penguasaan (56-65\%) kualifikasi cukup berjumlah 3 orang $(6,98 \%)$.

Berdasarkan hasil penelitian menunjukkan bahwa penguasaan kosakata memberikan kontribusi terhadap menulis, yaitu sebesar $19,8 \%$ karena $t_{\text {hitung }}>t_{\text {tabel }}$ atau $3,182>2,629$ dan memiliki persamaan regresi sederhana $\hat{Y}=33,87+0,20 \mathrm{X}_{2}$. Hal ini berarti keterampilan menulis dipengaruhi oleh penguasaan kosakata.

Selanjutnya, menurut Nurgiyantoro (2012:213) penguasaan kosakata dapat dibedakan ke dalam penguasaan bersifat reseptif dan produktif, kemampuan untuk memahami dan mempergunakan kosakata. Kemampuan memahami kosakata terlihat dalam kegiatan membaca dan menyimak, sedangkan kemampuan mempergunakan kosakata tampak dalam kegiatan menulis dan berbicara. Oleh karena itu, penguasaan kosakata berperan untuk kegiatan yang bersifat reseptif dan produktif. Menulis merupakan sesuatu kegiatan yang produktif karena siswa membutuhkan kosakata yang memadai untuk mengembangkan ide dan gagasannya menjadi sebuah tulisan yang utuh.

Temuan penelitian ini juga didukung oleh Atmazaki (2006:54) yang menjelaskan bahwa penguasan kosakata dapat ditambah dengan berbagai cara, yaitu dengan mencari dan menguasainya melalui kamus, baik kamus 
umum maupun kamus khusus, seperti kamus sinonim, kamus istilah ilmu pengetahuan, dan kamus ungkapan. Penguasaan kosakata juga bisa meningkat dengan memilih kata karena nuansa dan keluasan maknanya. Seseorang memilih kata dengan alasan tertentu sehingga dasar pemilihan katanya juga tertentu. Ini merupakan cara untuk menambah penguasaan kosakata.

Berdasarkan hasil penelitian dan beberapa pendapat ahli di atas, dapat disimpulkan bahwa penguasaan kosakata memiliki peranan yang penting dalam kegiatan menulispenguasaan kosakata siswa akan memudahkan siswa untuk menyampaikan ide dalam bentuk tulisan. Peningkatan penguasaan kosakata akan meningkatkan keterampilan menulis teks eksposisi. Selain itu, penguasaan kosakata siswa bisa ditingkatkan dengan sering melakukan kegiatan membaca dan menulis.

Kontribusi Motivasi Belajar dan Penguasaan Kosakata secara Bersama-sama terhadap Keterampilan Menulis Teks Eksposisi

Tes keterampilan menulis teks eksposisi berbentuk tes unjuk kerja. Berdasarkan hasil analisis data diperoleh nilai tertinggi sebesar 93,50 dan nilai terendah 58,50, nilai rata-rata sebesar 77,33, dan standar deviasi sebesar 7,77. Berikut ini gambaran keterampilan menulis teks eksposisi dibuat dalam bentuk diagram batang.

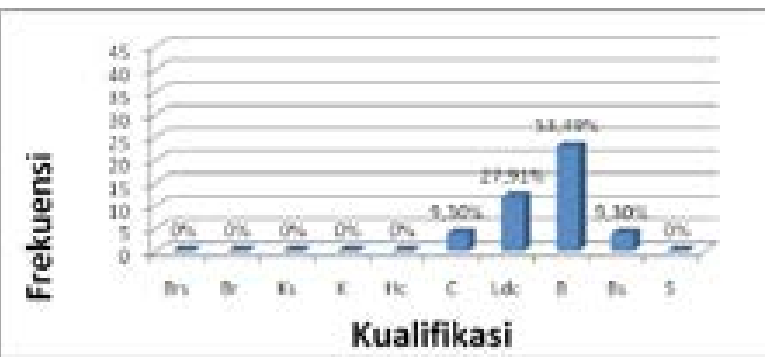

Gambar 3. Diagram Batang Keterampilan Menulis Teks Eksposisi
Diagram batang gambar 3 di atas menunjukkan bahwa keterampilan menulis teks eksposisi siswa kelas X MAN 1 Bukittinggi secara keseluruhan dikelompokkan menjadi empat kategori sebagai berikut. Pertama, siswa yang mendapat nilai tertinggi terdiri atas 4 orang $(9,30 \%)$ dengan kualifikasi baik sekali (86-95\%). Kedua, yang berada pada tingkat penguasaan (76-85\%) kualifikasi baik berjumlah 23 orang (53,49\%). Ketiga, yang berada pada tingkat penguasaan (6675\%) kualifikasi lebih dari cukup berjumlah 12 orang $(327,91 \%)$. Keempat, yang berada pada tingkat penguasaan (56-65\%) kualifikasi cukup berjumlah 4 orang $(9,30 \%)$.

Berdasarkan hasil penelitian, diketahui bahwa motivasi belajar dan penguasaan kosakata secara bersama-sama memberikan kontribusi terhadap menulis teks eksposisi, yaitu $26,4 \%$ karena $F_{\text {hitung }}>F_{\text {tabel }}$ atau 7,33> 3,23 dan memiliki persamaan regresi $\hat{Y}=$ $33,87+0,35 \mathrm{X}_{1}+0,20 \mathrm{X}_{2}$. Hal ini menunjukkan bahwa keterampilan menulis teks eksposisi dipengaruhi oleh motivasi belajar dan penguasaan kosakata.

Temuan penelitian ini didukung oleh Slamet (2008) yang menjelaskan bahwa secara umum keterampilan menulis siswa dipengaruhi oleh dua faktor, yaitu faktor kebahasaan dan faktor nonkebahasaan. Faktor kebahasaan meliputi penggunaan kaidah bahasa tulis, penguasaan kosakata, penggunaan kalimat efektif, penguasaan semantik, penguasaan paragraf, dan wacana. Sementara itu, faktor nonkebahasaan meliputi sikap, minat, motivasi, kebiasaan, dan lain-lain.

Berdasarkan hasil analisis ketiga hipotesis penelitian, maka ketiga hipotesis yang diajukan dalam penelitian ini dapat diterima. Berikut pola korelasi dan kontribusi dari ketiga variabel penelitian tersebut. 


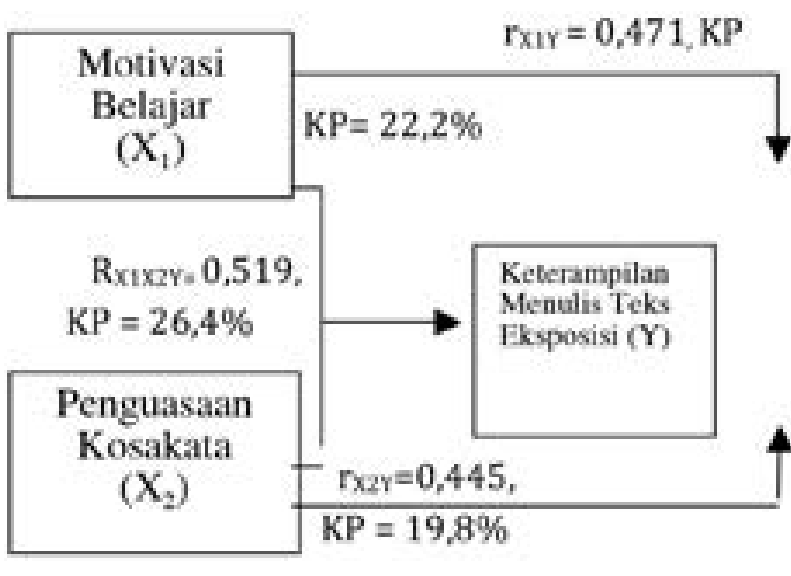

Gambar 1. Pola Korelasi dan Kontribusi Ketiga Variabel Penelitian

Berdasarkan besar kontribusi motivasi belajar dan penguasaan kosakata terhadap keterampilan menulis teks eksposisi, dapat disimpulkan bahwa motivasi memiliki kontribusi yang lebih besar terhadap keterampilan menulis teks eksposisi dibandingkan dengan penguasaan kosakata. Oleh sebab itu, apabila ingin meningkatkan keterampilan menulis teks eksposisi, maka motivasi belajar dan penguasaan kosakata harus diiberikan kepada siswa.

\section{PENUTUP}

Berdasarkan temuan mengenai kontribusi motivasi belajar dan penguasaan kosakata terhadap keterampilan menulis teks eksposisi siswa kelas X MAN 1 Bukittinggi, maka diperoleh hasil sebagai berikut.

Pertama, motivasi belajar memberikan kontribusi yang signifikan terhadap keterampilan menulis teks eksposisi siswa kelas X MAN 1 Bukittinggi. Hal ini terbukti bahwa motivasi belajar memberikan kontribusi sebesar 22,2\% terhadap keterampilan menulis teks eksposisi karena $t_{\text {hitung }}>t_{\text {tabel }}$ atau 3,418> 2,629. Kemudian, koefisien korelasi motivasi belajar dengn keterampilan mrnulis teks eksposisi tergolong cukup. Kedua, penguasaan kosakata memberikan kontribusi yang signifikan terhadap keterampilan menulis teks eksposisi siswa kelas X MAN 1 Bukittinggi. Hal ini terbukti bahwa penguasaan kosakata memberikan kontribusi terhadap keterampilan menulis teks eksposisi sebesar 19,8\% karena $t_{\text {hitung }}>t_{\text {tabel }}$ atau 3,182 >2,629. Kemudian, koefisien korelasi penguasaan kosakata dengan keterampilan menulis teks eksposisi tergolong cukup.

Ketiga, motivasi belajar dan penguasaan kosakata secara bersama-sama memberikan kontribusi yang signifikan terhadap keterampilan menulis teks eksposisi siswa kelas $X$ MAN 1 Bukittinggi. Hal ini terbukti bahwa motivasi belajar dan penguasaan kosakata secara bersama-sama memberikan kontribusi terhadap keterampilan menulis teks eksposisi sebesar 26,4\% terhadap keterampilan menulis teks eksposisi karena $\mathrm{F}_{\text {hitung }}>\mathrm{F}_{\text {tabel }}$ atau 7,33 > 3,23 . Kemudian, koefisien korelasi motivasi belajar dan penguasaan kosakata secara bersama-sama dengan keterampilan menulis teks eksposisi tergolong cukup.

Temuan penelitian ini menunjukkan bahwa keterampilan menulis teks eksposisi siswa akan meningkat apabila motivasi belajar dan penguasaan kosakata mereka juga meningkat. Hal ini disebabkan motivasi belajar dan penguasaan kosakata diperlukan dalam mengembangkan tulisan dalam bentuk teks eksposisi. Oleh karena itu, disarankan kepada guru agar lebih fokus memberikan dorongan untuk menulis kepada siswa dan memberikan pelatihan-pelatihan yang memungkinkan siswa memperbanyak penguasaan kosakatanya.

\section{DAFTAR PUSTAKA}

Atmazaki. 2006. Kiat-kiat Mengarang dan Menulis. Padang: Yayasan Citra Budaya Indonsia. 
Chaer, Abdul. 2007. Leksikologi dan Leksikografi Indonesia. Jakarta: Rineka Cipta.

Evensen, Sarah Charlotte. 2008. "Exposing The Essay: A study of Ninth Grades and Expository Writing". Journal of Educational Resources Information Center (ERIC), (Online), (diunduh 20 Februari 2016).

Finoza, Lamuddin. 2010. Komposisi Bahasa Indonesia. Jakarta: Diksi InsanMulia.

Hamalik, Oemar. 2009. Psikologi Belajar Mengajar. Bandung: Sinar Baru Algesindo.

Keraf, Gorys. 1995. Eksposisi. Jakarta: Grasindo.

Mahsun. 2014. Teks dalam Pembelajaran Bahaa Indonesia Kurikulum 2013. Jakarta: PT Raja Grafindo Persada.
Nurgiyantoro. 2012. Penilaian Pembelajaran Bahasa. Yogyakarta: BPFE.

Kemendikbud. 2013. Permendikbud Nomor 69 Tahun 2013 tentang KD dan Struktur Kurikulum SMA/MA. Jakarta: Menteri Pendidikan dan KebudayaanRepublik Indonesia.

Sardiman, AM. 2009. Interaksi dan Motivasi Belajar Mengajar. Jakarta: PT Raja Grafindo Persada.

Slamet, St. Y. 2008. Dasar-dasar Keterampilan Berbahasa Indonesia. Surakarta: UNS Press.

Sulasmi. 2013. "Hubungan Penguasaan Kosakata dan Kemampuan Menyusun Kalimat Efektif dengan Keterampilan Menulis Eksposisi". J- Simbol (Bahasa, Sastra, dan Pembelajarannya) Vol. 1 No.1, (Online), (http://jurnal.fkip.unila.ac.id, diakses 25 Agustus 2015). 